\title{
Review of 14 drowning publications based on the Utstein style for drowning
}

\author{
Allart M. Venema ${ }^{1 *}$, Anthony R. Absalom', Ahamed H. Idris ${ }^{2}$ and Joost J. L. M. Bierens ${ }^{3,4}$
}

\begin{abstract}
Background: The Utstein style for drowning (USFD) was published in 2003 with the aim of improving drowning research. To support a revision of the USFD, the current study aimed to generate an inventory of the use of the USFD parameters and compare the findings of the publications that have used the USFD.

Methods: A search in Pubmed, Embase, the Cochrane Library, Web of Science and Scopus was performed to identify studies that used the USFD and were published between 01-10-2003 and 22-03-2015. We also searched in Pubmed, Embase, the Cochrane Library, Web of Science, and Scopus for all publications that cited the two publications containing the original ILCOR advisory statement introducing and recommending the USFD. In total we identified 14 publications by groups that explicitly used elements of the USFD for collecting and reporting their data.

Results: Of the 22 core and 19 supplemental USFD parameters, 6-19 core (27-86\%) and 1-12 (5-63\%) supplemental parameters were used; two parameters (5\%) have not been used in any publication. Associations with outcome were reported for nine core (41\%) and five supplemental (26\%) USFD parameters. The USFD publications also identified nonUSFD parameters related to outcome: initial cardiac rhythm, time points and intervals during resuscitation, intubation at the drowning scene, first hospital core temperature, serum glucose and potassium, the use of inotropic/vasoactive agents and the Paediatric Index of Mortality 2-score.

Conclusions: Fourteen USFD based drowning publications have been identified. These publications provide valuable information about the process and quality of drowning resuscitation and confirm that the USFD is helpful for a structured comparison of the outcome of drowning resuscitation.
\end{abstract}

Keywords: Drowning, Utstein, Resuscitation

\section{Background}

In 2003, a consensus-based ILCOR advisory statement recommended the Utstein style for drowning (USFD) for use in planning of, and reporting of the results of drowning studies to improve the quality and comparability of drowning studies $[1,2]$. Since 2003 the USFD has been used to study drowning, which is a leading cause of accidental death worldwide, with an estimated death toll of 372.000 persons per year [3-17]. The USFD template consists of 22 core parameters that the statement recommended should be included in all drowning studies, and 19 supplemental parameters that are considered to be less important or are difficult to collect (Table 1).

\footnotetext{
* Correspondence: a.m.venema@umcg.nl

${ }^{1}$ Department of Anaesthesiology, University Medical Center Groningen, University of Groningen, Hanzeplein 1, Huispostcode EB 32, Postbus 30001, 9700 RB Groningen, The Netherlands

Full list of author information is available at the end of the article
}

The aim of this study was to generate an inventory of USFD usage during the more than 10 years since it was published, and to review and compare the findings of the publications that have used the USFD. This study elaborates on an initial study that was performed to support the revision process that generated the revised USFD, published in 2017 [18, 19]. Both the revised USFD and this current study will contribute to improvements in the uniformity of data collection and reporting, as recommended by the WHO in their recent document "Global Report on Drowning: preventing a leading killer" [17].

\section{Methods}

A literature search was performed to identify peerreviewed publications, concerning drowning that had used the USFD $[1,2]$ and were published between 01-10-2003 
Table 1 Overview of core and supplemental USFD parameters

\begin{tabular}{|c|c|c|}
\hline & USFD parameters & Core/Supplemental \\
\hline \multirow[t]{8}{*}{ Victim Information } & Victim identifier & Core \\
\hline & Gender & Core \\
\hline & Age & Core \\
\hline & Race or Ethnic category & Supplemental \\
\hline & Date and time of day of incident & Core \\
\hline & Residence & Supplemental \\
\hline & Precipitating event & Core \\
\hline & Preexisting illness & Supplemental \\
\hline \multirow[t]{17}{*}{ Scene information } & Witnessed & Core \\
\hline & Body of water & Core \\
\hline & Water/liquid type & Supplemental \\
\hline & Approximate water temperature & Supplemental \\
\hline & Time of submersion & Supplemental \\
\hline & Time of removal of victim from water & Supplemental \\
\hline & Unconscious when removed from water & Core \\
\hline & Cyanosis & Supplemental \\
\hline & Resuscitation before EMS arrived & Core \\
\hline & Method of CPR & Supplemental \\
\hline & EMS called & Core \\
\hline & EMS vehicle dispatched & Supplemental \\
\hline & Time of first EMS assessment & Supplemental \\
\hline & Initial vital signs & Core \\
\hline & $\begin{array}{l}\text { Oxygen saturation, temperature, blood pressure, } \\
\text { pupillary reaction }\end{array}$ & Supplemental \\
\hline & Time of first EMS resuscitation attempt & Core \\
\hline & Neurological status & Core \\
\hline \multirow{7}{*}{$\begin{array}{l}\text { Emergency Department Evaluation } \\
\text { and Treatment }\end{array}$} & Vital signs & Core \\
\hline & Oxygen hemoglobin saturation & Core \\
\hline & $\begin{array}{l}\text { Arterial blood gas analysis, if unconscious or } \\
\mathrm{SaO} 2<95 \% \text { on room air }\end{array}$ & Core \\
\hline & Initial neurological status & Core \\
\hline & Pupillary reaction & Supplemental \\
\hline & Airway and ventilation requirements & Core \\
\hline & Toxicology testing & Supplemental \\
\hline \multirow[t]{3}{*}{ Hospital Course } & Airway and ventilation requirements & Core \\
\hline & $\begin{array}{l}\text { Serial neurological function (admission, } 6 h, 24 h \text {, } \\
72 h \text {, discharge) }\end{array}$ & Supplemental \\
\hline & Complicating illnesses & Supplemental \\
\hline \multirow[t]{6}{*}{ Disposition } & Alive or dead & Core \\
\hline & Date of hospital discharge & Core \\
\hline & Neurological outcome at hospital discharge & Core \\
\hline & Quality of life & Supplemental \\
\hline & Cause of death & Supplemental \\
\hline & Other injuries and morbidities & Supplemental \\
\hline
\end{tabular}


(month of the publication of the USFD) and 22-03-2015 (the latter date was arbitrarily chosen and was shortly before the revision process of the USFD was completed).

Pubmed search terms were: "Drowning"[Mesh] OR drown"[tw]) AND utstein[tw]; Embase search terms were: 'drowning'/exp. OR drown*:ab,ti AND utstein:ab,ti; Cochrane Library and Web of Science search terms were: drown* AND utstein; the Scopus search term used was "drowning AND Utstein".

The search provided 15 publications from Pubmed, 22 from Embase, none from the Cochrane Library, 28 from Web of Science and 17 from Scopus. Altogether, the systematic literature search identified 37 different publications (Fig. 1). These publications were independently reviewed by two authors (AV and AA), to identify those that explicitly stated an a priori intention to base their study on the USFD. After exclusion of drowning publications that did not explicitly mention that data collection was based on the USFD parameters, eight USFD based drowning publications remained [3-10]. Of the 29 publications that had not used the USFD, three were drowning publications of which data collection was based on the Utstein style for out of hospital cardiac arrest $[20,21]$, or did not describe the use of any Utstein template [22], four were publications on resuscitation that included only a few drowning patients [23-26], one was a resuscitation publication that excluded drowning victims [27], five were reviews [28-32], and 16 were other types of publications (definition of drowning, editorials, abstracts, letter to the editor, non-English language articles, post mortem examinations, book chapter) [33-48].

To enhance the robustness of the search, we additionally searched in Pubmed, Embase, the Cochrane Library, the Web of Science and Scopus for all publications that cited the two publications containing the original ILCOR advisory statement introducing and recommending the USFD [1,2]. This revealed a total of six further publications that matched the inclusion criteria for our study, but had not been identified by the initial search strategy [11-16].

A total of 14 publications were thus included in the current analysis [3-16]. The individual publications were
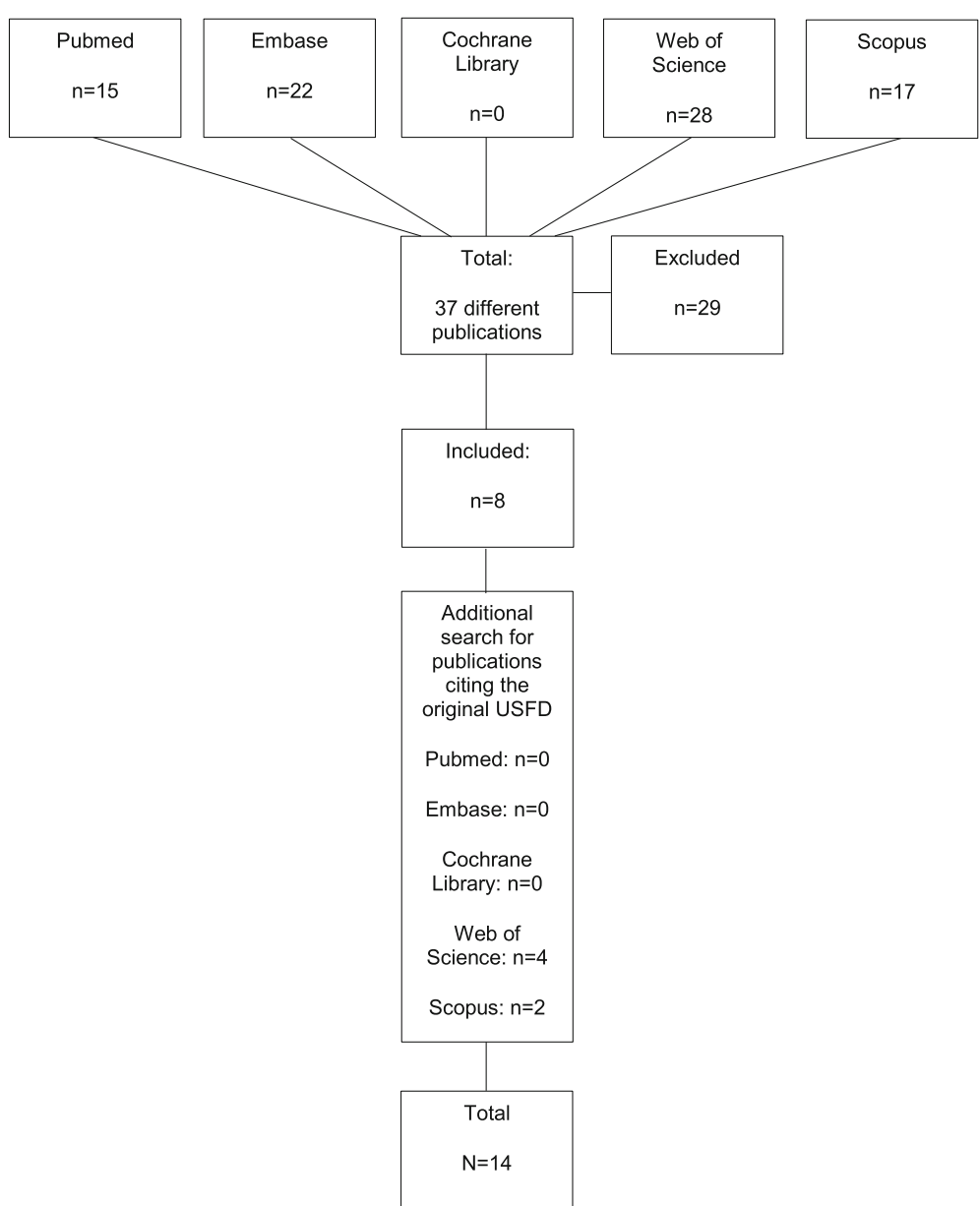

Fig. 1 Flowchart of search strategy 
subsequently analysed independently by two reviewers (AV, AA) to identify the USFD parameters used by each publication, the information these USFD parameters provided, and USFD as well as non-USFD parameters related to outcome. In case of disagreement, discussion continued until agreement was reached.

We decided a priori to report all parameters for which an association with outcome was published, regardless of the number of publications in which they were used and to limit the reporting of non-outcome related parameters to those parameters that had been reported in five or more publications. Because the objective of our study was to report the use of the USFD, it was also decided a priori not to combine the data of the publications for a meta-analysis or to perform any statistical analysis of the patient data [49].

\section{Results}

Table 2 summarises the 14 USFD drowning publications, in which $27-86 \%$ of the core and $5-63 \%$ of the supplemental USFD parameters were used.

Table 2 Fourteen drowning publications and their use of the 22 core and 19 supplemental USFD parameters

\begin{tabular}{|c|c|c|c|c|c|c|c|}
\hline \multirow[t]{2}{*}{ Study } & \multirow{2}{*}{$\begin{array}{l}\text { Year of } \\
\text { publication }\end{array}$} & \multirow[t]{2}{*}{ Country } & \multirow[t]{2}{*}{ Study description } & \multirow{2}{*}{$\begin{array}{l}\text { Victims } \\
(N)\end{array}$} & \multirow{2}{*}{$\begin{array}{l}\text { Category } \\
\text { Adults/Children }\end{array}$} & \multicolumn{2}{|c|}{ USFD parameters } \\
\hline & & & & & & Core $(\%)$ & Supplemental (\%) \\
\hline Eich et al. [3] & 2007 & Germany & $\begin{array}{l}\text { Retrospective chart review on out of } \\
\text { hospital cardiac arrest }(\mathrm{OHCA}) \text { due to } \\
\text { drowning and sustained resuscitation } \\
\text { with } \mathrm{CPB}\end{array}$ & 12 & Children & $19(86.4 \%)$ & $11(57.9 \%)$ \\
\hline Grmec et al. [4] & 2009 & Slovenia & $\begin{array}{l}\text { Retrospective chart review comparing } \\
\text { the data of } 528 \text { primary cardiac arrest } \\
\text { victims with } 32 \text { drowning victims }\end{array}$ & 32 & Adults & $8(36.4 \%)$ & $3(15.8 \%)$ \\
\hline Youn et al. [5] & 2009 & South Korea & $\begin{array}{l}\text { Prospective study on OHCA due to } \\
\text { drowning }\end{array}$ & 131 & $\begin{array}{l}\text { Adults and } \\
\text { Children }\end{array}$ & 19 (86.4\%) & $8(42.1 \%)$ \\
\hline Venema et al. [6] & 2010 & Netherlands & $\begin{array}{l}\text { Retrospective study on bystander } \\
\text { rescue and resuscitation }\end{array}$ & 343 & $\begin{array}{l}\text { Adults and } \\
\text { Children }\end{array}$ & $14(63.6 \%)$ & $12(63.2 \%)$ \\
\hline Choi et al. [7] & 2012 & South Korea & $\begin{array}{l}\text { Retrospective chart review on OHCA } \\
\text { due to drowning and treatment with } \\
\text { therapeutic hypothermia }\end{array}$ & 20 & Adults & $15(68.2 \%)$ & $8(42.1 \%)$ \\
\hline Vähätalo et al. [8] & 2014 & Finland & $\begin{array}{l}\text { Retrospective chart review of } \\
\text { drowning children under } 16 \text { years of } \\
\text { age who were hospitalized or died } \\
\text { due to drowning }\end{array}$ & 58 & Children & $12(54.5 \%)$ & $4(21.1 \%)$ \\
\hline Joanknegt et al. [9] & 2015 & South Africa & $\begin{array}{l}\text { Retrospective chart review of } \\
\text { drowning victims to inform } \\
\text { prevention strategies }\end{array}$ & 75 & Children & $13(59.1 \%)$ & $5(26.3 \%)$ \\
\hline Kieboom et al. [10] & 2015 & Netherlands & $\begin{array}{l}\text { Retrospective chart review on } \\
\text { hypothermic drowning victims } \\
\text { with } \mathrm{OHCA}\end{array}$ & 160 & Children & $13(59.1 \%)$ & $5(26.3 \%)$ \\
\hline Hunsucker et al. [11] & 2011 & USA & $\begin{array}{l}\text { Retrospective chart review on } \\
\text { rescue reports of drowning victims } \\
\text { with loss of spontaneous respiration } \\
\text { in a waterpark environment }\end{array}$ & 32 & $\begin{array}{l}\text { Adults and } \\
\text { Children }\end{array}$ & $6(27.3 \%)$ & $2(10.5 \%)$ \\
\hline Allan et al. [12] & 2010 & USA & $\begin{array}{l}\text { retrospective chart review on } \\
\text { US military drowning victims in } \\
\text { in Iraq }\end{array}$ & 8 & Adults & $10(45.5 \%)$ & $11(57.9 \%)$ \\
\hline Ma et al. [13] & 2010 & China & $\begin{array}{l}\text { matched case control study on } \\
\text { non-fatal drowning }\end{array}$ & 325 & Children & $7(31.8 \%)$ & $1(5.3 \%)$ \\
\hline Wanscher et al. [14] & 2012 & Denmark & $\begin{array}{l}\text { Retrospective review of a boating } \\
\text { accident involving drowning victims } \\
\text { and non-drowning victims with } \\
\text { accidental hypothermia. }\end{array}$ & 15 & $\begin{array}{l}\text { Adults and } \\
\text { Children }\end{array}$ & $18(81.1 \%)$ & $10(52.6 \%)$ \\
\hline Orlowski et al. [15] & 2012 & USA & $\begin{array}{l}\text { Retrospective chart review on } \\
\text { drowning occurring during a visit } \\
\text { to relatives or friends }\end{array}$ & 100 & Children & $8(36.4 \%)$ & $3(15.8 \%)$ \\
\hline Champigneulle et al. [16] & 2015 & France & $\begin{array}{l}\text { Retrospective chart review on } \\
\text { drowning victims with } \mathrm{OHCA} \\
\text { treated with extracorporeal life } \\
\text { support }\end{array}$ & 43 & $\begin{array}{l}\text { Adults and } \\
\text { Children }\end{array}$ & $17(77.3 \%)$ & $9(47.4 \%)$ \\
\hline
\end{tabular}


Table 3 Overview of the USFD parameters related to outcome

\begin{tabular}{|c|c|c|}
\hline $\begin{array}{l}\text { USFD parameters } \\
\text { (Core/Supplemental) }\end{array}$ & Total use $(n)$ & Overall description \\
\hline \multicolumn{3}{|l|}{ Victim Information } \\
\hline Age (Core) & 14 & $\begin{array}{l}\text { Age is described as mean, median or range: } \\
\text { Mean age } 3 \text { years and } 5 \text { months- } 47.5 \text { years } \\
{[3-8,12,16] \text {; median age } 2-2.2 \text { years }[9,10] \text {; }} \\
\text { Range } 1-60 \text { years }[11,13-15] \text {. }\end{array}$ \\
\hline $\begin{array}{l}\text { Date and time of day of incident } \\
\text { (Core) }\end{array}$ & $6 / 9$ & $\begin{array}{l}\text { Six publications describe the time of day } \\
{[3,5,6,8,13,14] \text { and nine publications }} \\
\text { describe the season the drowning occurred in } \\
{[3,5-8,10,11,13,14] \text {. Four publications }} \\
\text { describe that } 39-100 \% \text { of drownings occur } \\
\text { during the daytime }[3,5,8,13] \text { One } \\
\text { publication reports that } 67 \% \text { of drownings } \\
\text { occur between } 12 \mathrm{AM} \text { and } 8 \text { PM and } 33 \% \text { of } \\
\text { drownings from } 9 \text { PM to } 11 \text { AM }[6] \text {. } \\
\text { Forty-seven to One hundred percent of } \\
\text { drowings are reported to occur between } \\
\text { springtime and the end of the summer } \\
{[3,5-8,10,11,13] \text {. }}\end{array}$ \\
\hline
\end{tabular}

\section{Scene information}

Witnessed (Core)

Approximate water temperature (Supplemental)

Time of submersion (Supplemental)

Resuscitation before EMS arrived (Core)

Oxygen saturation, temperature, blood pressure, pupillary reaction (Supplemental)
Significant relation with outcome

One publication shows that survivors are significantly younger than non-survivors $(38.9 \pm 12.6$ versus $56.6 \pm 18.7 ; p=0.03)$ [4].

One publication shows that outcome after drowning is significantly better in winter compared to other seasons: odds ratio 4.6 $(1.4-15.1), p=0.013$ [10].

One publication shows that survivors are The drowning event is not witnessed in the majority of cases (58-81\%) in four publications $[3,4,8,9]$. In another five publications the drowning is witnessed in the majority $[5-7,10,16]$. In one publication the drowning was witnessed in 100\% (by fellow victims) [14].

In one publication a median water temperature for survivors of 20.4 (Interquartile range 13.7, 27.0) and $20.0^{\circ} \mathrm{C}$ (interquartile range $8.6,23.8$ ) was reported $(p=0.184)$ [8]. In three publications a large range $\left(0-28^{\circ} \mathrm{C}\right)$ was reported $[3,10,16]$. In one study the water temperature was $2^{0} \mathrm{C}$ for all victims [14]. In one publication the water temperature was described as warm (14\%), cold $(84 \%$, or ice-cold (3\%) [6].

The duration of submersion is described in different ways (median, mean, ordinal) but ranges from $<1$ to 45 min $[3,5-12]$. One publication described a submersion time of 10 min or more in $2 \%$ of the victims [15].

Resuscitation attempts before the arrival of EMS varies between 24 and 93\% [3-6, 8-11]. In one publication this parameter was described in 19\% of the cases, of which 79\% were resuscitated before EMS arrival [15]. In one publication BLS was immediately started after removal from the water in $100 \%$ of the victims by police officers or firefighters before ALS providers arrived [16].

In one publication at least one of these four parameters information is available in 4 out of 343 victims [6]. Hypothermia is reported in four publications $[3,12,14,16]$. Pupillary reactions are described in three publications $[3,9,12]$. more likely to have had a witnessed drowning event than non-survivors (76 versus $61 \% ; p=0.036$ ) [5].

In one publication the water temperature was lower for $24 \mathrm{~h}$ survivors among victims treated with $\operatorname{ECLS}(p=0.04)[16]$.

A longer duration of submersion is significantly associated with bad outcome in four publications [5, 8-10]. Two publications report no significant difference $[3,7]$.

One publication shows that drowning victims that survive have significantly more bystander CPR than non-survivors (57 versus $17 \% ; p=0.03$ ) [4]. A significant relation between bystander resuscitation and outcome is not found in three publications $[5,8,10]$.

In one publication unresponsive and dilated pupils is significantly related with bad outcome $(p<0.001)$ [9]. In one publication the first prehospital core temperature was lower in the $24 \mathrm{~h}$ survivors among patients treated with 
Table 3 Overview of the USFD parameters related to outcome (Continued)

USFD parameters $\quad$ Total use $(n)$ Overall description $\quad$ Significant relation with outcome

$\operatorname{ECLS}(p=0.07)$ [16]. In this same publication the association between a first prehospital core temperature of $\leq 26^{\circ} \mathrm{C}$ and serum potassium level between 4.2 and 6.0 identified $24 \mathrm{~h}$ survivors among patients treated with ECLS with $100 \%$ sensitivity $(95 \% \mathrm{Cl}$ : 28-100\%) and specificity (95\% Cl: $71-100 \%)$

Time of first EMS resuscitation attempt (Core)

Emergency Department Evaluation and Treatment

Vital signs (Core)

Arterial blood gas analysis, if unconscious or $\mathrm{SaO} 2<95 \%$ on room air (Core)
The mean time interval is described in two publications $[5,7]$.

In another publication this parameter is included, but the information is not available in any victims [6].

Vital signs are absent in 20 to $100 \%$ of the victims on arrival at the $E D$ $[3-5,7,9,10,14]$. In one publication all victims had asystole at arrival at the ED [16].

Hypoxemia, acidosis, and hypercarbia are common findings $[3,5,7-10,14,16]$.

The GCS is 3 at the ED in all patients in three publications (in only one patient in one of these studies a palpable pulse was reported) $[3,5,7]$. In one publication the median Glasgow Coma Score (GCS) ranged between 11.5 in survivors and 3 in non-survivors [8]. In one publication the GCS was described as $<5$ ( $41 \%$ good outcome, $18 \%$ neurologic sequelae, $41 \%$ death) or $\geq 5$ ( $98 \%$ good outcome, $2 \%$ death) [9]. In one publication the median GCS was 3 [10]. In one publication the GCS ranged from 3 to 15 [14]. One study described that none of the victims had clinical signs of life [16].

In three publications, fixed and dilated pupils were reported in $47 \%, 95 \%$ and $100 \%$ of victims $[5,7,14]$. In one publication pupillary reactions are described as reactive $(n=44)$, sluggish $(n=6)$, unreactive not dilated $(n=6)$, or unreactive dilated $(n=5)$ [9].
The time of first EMS resuscitation is found to be significantly associated with outcome in one publication: $11.2 \pm 5.6 \mathrm{~min}$ in survivors versus $21.4 \pm 12.8 \mathrm{~min}$ in non-survivors: $p=<0.001[5]$.

In one publication resuscitation at arrival in the ED is negatively associated with outcome $(p<0.001$, OR $0.03,95 \% \mathrm{Cl}$ $0.01-0.13)$ [9]. In the same publication hypothermia is significantly related to bad outcome $(p<0.001$, OR 18.00 $95 \%$ Cl 3.35-96.74). In one publication $24 \mathrm{~h}$ survivors among patients treated with ECLS had a significantly lower in hospital initial core temperature $(p=0.004)[16]$.

The more severe the acidosis, the worse outcome is $(p<0.001-0.014)$ [8-10]. In one publication an initially lower $\mathrm{pH}$ relates to hospital mortality ( $p=0.008$ ) [7]. Drowning cardiac arrest victims have a higher initial pCO2 compared to non-drowning victims in cardiac arrest $(p<0.001)$. Endtidal CO2 after $1 \mathrm{~min}$ of CPR ( $p$ 0.02) and the final endtidal CO2 $(p<0.001)$ were independent factors for survival [10]. Less negative base excess is related to better outcome. $(p<0.001-0.001)[8,10]$

A low GCS is significantly associated with bad outcome in three publications $(p<0.001)[8-10]$.

Unreactive dilated pupils in the ED are significantly related to bad outcome in one publication $(p<0.001$; OR 0.01; $95 \% \mathrm{Cl} 0.04-0.23)$ [9]. 
Table 3 Overview of the USFD parameters related to outcome (Continued)

\begin{tabular}{|c|c|c|c|}
\hline $\begin{array}{l}\text { USFD parameters } \\
\text { (Core/Supplemental) }\end{array}$ & Total use $(n)$ & Overall description & Significant relation with outcome \\
\hline $\begin{array}{l}\text { Airway and ventilation requirements } \\
\text { (Core) }\end{array}$ & 7 & $\begin{array}{l}\text { In six publications } 100 \% \text { of the patients are } \\
\text { ventilated mechanically or manually } \\
{[3,5,7,9,10,16] \text {. In one publication it was }} \\
\text { reported that one patient was intubated } \\
\text { and ventilated }[14] \text {. }\end{array}$ & $\begin{array}{l}\text { Intubation at the ED }(p=0.002) \text { is } \\
\text { significantly related to bad outcome in } \\
\text { one publication [9]. }\end{array}$ \\
\hline \multicolumn{4}{|l|}{ Hospital Course } \\
\hline $\begin{array}{l}\text { Serial neurological function } \\
\text { (admission, } 6 \text { h, } 24 \text { h, } 72 \text { h, discharge) } \\
\text { (Supplemental) }\end{array}$ & 3 & $\begin{array}{l}\text { In one publication myoclonic or seizure } \\
\text { activity (including treatment with } \\
\text { medications), loss of pupillary response, } \\
\text { absent motor response to pain, } \\
\text { somatosensory evoked potentials (SSEPs), } \\
\text { and the use of brain imaging are described } \\
\text { [7]. One publication only describes the use of } \\
\text { a CT scan [12]. One publication describes the } \\
\text { use of electroencephalographic recordings, } \\
\text { SSEPs, magnetic resonance imaging and the } \\
\text { use of biomarkers (neuron specific enolase } \\
\text { and protein S100B) [14]. }\end{array}$ & $\begin{array}{l}\text { Neurological function testing, } \\
\text { somatosensory evoked potentials } \\
\text { (SSEPs), brain imaging (computed } \\
\text { tomography or diffusion-weighted } \\
\text { imaging) and neurological examination } \\
\text { of motor response to motor response to } \\
\text { pain after } 3 \text { days, are significantly related } \\
\text { to bad outcome in one publication [7]. }\end{array}$ \\
\hline
\end{tabular}

Table 3 describes the nine core (41\%) and five supplemental (26\%) USFD parameters related to outcome. Table 4 describes the 11 core (50\%) and six supplemental (32\%) USFD parameters not related to outcome that were reported in 5 or more of the publications. In total, 10 USFD parameters not related to outcome were reported in less than 5 of the 14 drowning publications: Race or Ethnic category $(n=2)$, Residence $(n=4)$, Time of removal of victim from water $(n=3)$, Cyanosis $(n=4)$, Time of first emergency medical services (EMS) assessment $(n=4)$, Oxygen haemoglobin saturation $(n=3)$, Toxicology testing $(n=0)$, Date of hospital discharge $(n=1)$, Quality of life $(n=0)$, Other injuries and morbidities $(n=3)$.

The USFD publications also included non-USFD parameters. The non-USFD parameters related to outcome are described below.

In one publication the first hospital core temperature of victims treated with extracorporeal life support (ECLS), $24 \mathrm{~h}$ survivors had a lower temperature than non-survivors $(p=0.004)$ [16].

Ten publications report the initial cardiac rhythm (at EMS arrival, at the emergency department (ED) and/or during hospital admission). With the exception of two studies $[14,16]$, the other studies showed that a shockable rhythm is rare (0-9\%) in drowning victims in need of resuscitation $[3-5,7-10,12]$. Three of the latter publications showed a relation between the initial cardiac rhythm and outcome [3, 9, 10].

Eleven publications included parameters that were related to the start or duration of basic life support (BLS), advanced life support (ALS), or interventions by EMS, either as time intervals or as time points $[3-5,7-12,14,16]$. An early start of resuscitation, rapid transfer to hospital and shorter duration of resuscitation were significantly related to better outcome $[4,5,7,10]$.

In one publication, intubation at the drowning scene was significantly related to bad outcome [9].

One publication concluded that glucose levels were significantly lower in survivors [8]. The relationship between serum potassium and outcome was inconsistent $[3,4,8,16]$.

The use of inotropes/vasoactive medications was related to outcome in three publications $[4,9,10]$. One of these publications concluded that more drowning victims that survived received vasopressin than nonsurvivors $(64 \%$ versus $22 \% ; p=0.03)$ [4]. The use of inotropic/vasoactive agents was associated with worse outcome in two publications $(p<0.001$ and $p=0.01)[9,10]$.

The Paediatric Index of Mortality 2-score for patients admitted to the intensive care unit (ICU) has been calculated in one publication and was significantly higher in non-survivors [9].

In 4 of the 14 identified publications the authors commented on the USFD and/or suggested alterations to the USFD. One publication, involving a study in which identification of non-USFD outcome related parameters was a secondary study goal, recommended inclusion of information on early BLS, serum potassium, rewarming speed after the use of cardiopulmonary bypass and the initial cardiac rhythm in the USFD [3]. Another publication, involving a study in which the feasibility of the USFD parameters was tested as a secondary study goal, suggested changing some parameters on victim and scene information, including rescue related parameters and rescue related injuries [6]. In this same publication the authors also suggested use of 'country of birth' instead of the USFD parameter 'race 
Table 4 The USFD parameters used in 5 or more of the 14 USFD drowning publications

\begin{tabular}{|c|c|c|}
\hline USFD parameters (Core/Supplemental) & Total use $(n)$ & Overall conclusions \\
\hline \multicolumn{3}{|l|}{ Victim Information } \\
\hline Victim identifier (Core) & 6 & Not related to a conclusion \\
\hline Gender (Core) & 14 & $\begin{array}{l}\text { Most drowning victims are male }(57-100 \%) \text { in } 12 \text { publications } \\
{[3-6,8-13,15,16] \text {. In one publication } 35 \% \text { of the victims are male }} \\
\text { [7]. In one publication the distribution is unclear due to a } \\
\text { contradiction in the reporting of this parameter [14]. }\end{array}$ \\
\hline Precipitating event (Core) & 10 & $\begin{array}{l}\text { The most frequently reported precipitating events are motor } \\
\text { vehicle or boating accidents, and swimming }[6,8,12-14] \text {. }\end{array}$ \\
\hline Pre-existing illness (Supplemental) & 5 & $\begin{array}{l}\text { Pre-existing illness is either not reported or not linked to outcome } \\
\text { in any of the publications }[3,5,6,8,12] \text {. }\end{array}$ \\
\hline
\end{tabular}

Scene information

Body of water (Core)

13

Water/liquid type (Supplemental)

11

Unconscious when removed from water (Core)
Drowning occurs mostly (66-100\%) in natural bodies of water such as rivers, lakes and canals in eight publications $[3,5-8,10,12-14,16]$. Two publications report that drowning occur predominantly (52 and $95 \%$ ) in private or public pools $[9,15]$. Another publication has only included drowning in swimming pools [11].

Seven publications predominantly (84-100\%) report fresh water drownings $[3,5-8,10,16]$. In one publication drowning in roadside ditches, canals and retention ponds are reported as the predominant water sources, however salinity was not determined [12]. In one publication all drownings occurred in salt water [14]. In the two publications where most drownings occurred in pools, the salinity of these pools was not specified $[9,15]$.

Four publications report that $83-100 \%$ of the victims were unconscious when removed from the water $[3,5,9,16]$. In two publications a minority were unconscious $[6,13]$. Two publications show an equal distribution $[12,14]$.

One publication only reported that the victims were resuscitated according to guidelines [16]. Five publications described in more detail how resuscitation was performed, based on which it seems that international guidelines were followed $[4-6,11,14]$. One of these publications reported that in $10 \%$ resuscitation was not performed according to guidelines (tapping on back, rubbing abdomen, pressing water out of lungs etc.) [6]. Another one of these publications described the use of abdominal trusts in and outside the water [11].

Calling the EMS is directly or indirectly reported in 11 publications but as such provides no relevant information.

Dispatch of the EMS is directly or indirectly reported in ten publications but as such provides no relevant information.

Two publications directly or indirectly reported that all victims were in cardiac arrest $[3,16]$. One publication reported that all victims had a Glasgow Coma Scale of 3 [5]. One publication reported that $53 \%$ of the victims were in cardiac arrest [14]. One publication described that the information was available in $0.3 \%$ of the victims but made no further specifications [6].

Two publications reported that all victims had a Glasgow Coma Scale of $3[3,5]$. One of these publications also reported fixed dilated pupils for all patients [3]. One publication reported that $16 \%$ of the victims were unconscious and $84 \%$ were conscious [6]. One publication reported that four patients (50\%) were comatose of which two had fixed dilated pupils with diffuse flaccid paralysis. This same publication also reported a mean initial Glasgow Coma Scale of 10.4 [12]. In one publication this information was indirectly available because all were in cardiac arrest [16]. 
Table 4 The USFD parameters used in 5 or more of the 14 USFD drowning publications (Continued)

\begin{tabular}{lll}
\hline USFD parameters (Core/Supplemental) & Total use $(n)$ & Overall conclusions \\
\hline $\begin{array}{l}\text { Hospital Course } \\
\text { Airway and ventilation requirements (Core) }\end{array}$ & 7 & $\begin{array}{l}\text { All seven publications that reported this parameter only globally } \\
\text { described it, which provided no real relevant information } \\
{[3,7,8,12,14-16] .}\end{array}$ \\
Complicating illnesses (Supplemental) & 6 & $\begin{array}{l}\text { Six publications report complicating illnesses such as pneumonia, } \\
\text { acute respiratory distress syndrome, pancreatitis, rhabdomyolysis, } \\
\text { disseminated intravascular coagulation acute renal failure, multiple } \\
\text { organ failure and septic shock [3, 5, } 7,9,12,16] \text {. In one of these } \\
\text { publications extubation stridor, minor neurologic deficits and } \\
\text { corneal ulceration are reported which all are resolved at the time } \\
\text { of discharge [9]. }\end{array}$
\end{tabular}

\section{Disposition}

Alive or dead (Core)

Neurological outcome at hospital discharge (Core)
14

10

Cause of death (Supplemental) 5

Survival is good (16-93\%) in most studies [3-12, 14, 15]. In one study only $5 \%$ of the victims survived [16]. One publication only reports non-fatal drowning [13].

In four publications $7-20 \%$ had a (Paediatric) Cerebral Performance Scale/Category (P)CPC score of one to two $[3,5,7,8]$. In one publication $85 \%$ of the patients had a CPC score of one to two [4]. In one publication $84 \%$ of the patients do not have any neurological complications, while $5.3 \%$ have irreversible neurological sequellae [9]. In one publication $11 \%$ of the patients have a (P)CPC score of three or less 1 year after the drowning incident [10]. In one publication hypoxic encephalopathy is reported in one victim (13\%) [12]. One publication described a median Functional Independence Measure of 115 (range 51-121) and a median extended Glasgow Coma Scale score of 4 (range 3-7) after 6 months [14]. In one publication two victims (5\%) survived to hospital discharge of which one had a CPC score (at discharge and at 6 months later) of one and one had a CPC score of three [16].

Five publications described causes of death such as multi organ failure, septic shock, cardiac arrest, respiratoy failure, severe brain injury and brain death $[3,7,10,12,16]$. or ethnic category' [6]. One publication suggested reporting 'time of submersion' as core parameter. Furthermore this same publication concluded that the USFD is applicable for reporting retrospective data of drowned children [8]. One publication promoted the USFD and suggested the creation of an international registry [16].

\section{Discussion}

Between 1-10-2003 and 22-3-2015, the USFD has been used in 14 USFD based drowning publications, which involved different populations, focus and methodology. The cumulative findings of the reports have identified 14 USFD parameters for whom associations with outcome were reported. Also non-USFD parameters related to outcome have been identified: initial cardiac rhythm, time points and intervals during resuscitation, intubation at the drowning scene, first hospital core temperature, serum glucose and potassium, the use of inotropic/vasoactive agents and the Paediatric Index of Mortality 2-score.
None of the 14 USFD based drowning publications included in this review used all USFD parameters. This is explained in part by the narrow focus of some of the publications, for example on the pre-hospital setting [6], and the differences in methodology of the publications. Furthermore, the results show that several parameters such as the age of the drowning victims were described inconsistently (mean, median or range). These inconsistencies are probably the result of both the preferences in data reporting by the individual researchers, as well as the fact that the USFD does not provide extensive advice on this matter. Such inconsistencies hinder the goal of this template that is designed to improve the quality and comparability of individual studies, in order to identify ways in which outcome can be improved. Despite these issues, the use of the USFD parameters has enabled a comparison of resuscitation outcome data from these different drowning publications during the review process.

Several researchers have included in their research additional parameters potentially related to drowning outcome and some have recommended the inclusion of these additional parameters in drowning research. 
This review of 14 USFD based studies was initiated at the start of the USFD revision process. Preliminary data were included in the consensus discussions that resulted in the revised USFD publications $[18,19]$. The results we report here, support the decision that was made to revise the USFD $[18,19]$. It is hoped that the revised USFD and this review will assist researchers in studying drowning and will encourage them to use the USFD parameters in their research. This might lead to a more complete use of the USFD and thereby improved comparability of drowning studies in the future. The results we report here will hopefully also help to inform future revisions to the USFD.

There are some limitations regarding the review process that should be mentioned. For the purpose of this review we have only focused on USFD based drowning publications. It is possible that other publications on drowning in the same time period might have demonstrated different results. By using the search terms and databases mentioned in the Methods section, the potential for missing relevant publications is minimized, but cannot be ruled out entirely.

The results of the reviewed publications displayed a variety of important information on the outcome and circumstances of drowning resuscitation. However, the authors realise that the USFD is only a tool to facilitate drowning resuscitation research. A recent publication concluded that the methodology of future drowning studies also needs to be based on unbiased high quality data and multi-variate analysis [49].

\section{Conclusions}

Between 2003 and 2015, 14 USFD based publications on drowning have been published. These publications have identified associations between several USFD as well as non-USFD parameters and outcome. None of the publications reported all USFD parameters and there were inconsistencies in the way the USFD parameters were reported. This negatively influenced a structured comparison of the USFD parameters between the studies. However, despite the difficulties these publications still show that the use of the USFD is helpful for a structured comparison of the outcome of drowning resuscitation and provides valuable information about the process and quality of drowning resuscitation.

The analysis also points at some limitations of the USFD and has identified important additional parameters that have been considered for a revised USFD.

\section{Abbreviations}

ALS: Advanced life support; BLS: Basic life support; ECLS: Extracorporeal life support; ED: Emergency department; EMS: Emergency medical services; ICU: Intensive care unit; USFD: Utstein style for drowning; WHO: World Health Organization

\section{Acknowledgements}

The authors would like to thank K. Sijtsma of the Medical Library of the University Medical Center Groningen for assistance in creating the search terms of this study

Funding

The research was not funded.

\section{Availability of data and materials}

The datasets used and/or analysed during the current study are available from the corresponding author on reasonable request.

\section{Authors' contributions}

All authors were involved in the conception and design of the review. AV and AA were involved in the acquisition of the data. AV, AA and JB were involved in the analysis and interpretation of the data. All authors have been involved in drafting the manuscript or revising it critically for important intellectual content. All authors have given final approval of the version to be published.

Ethics approval and consent to participate

Not applicable.

Consent for publication

Not applicable.

\section{Competing interests}

AV, Al and JB are members of the writing group on behalf of the '2015 Revised Utstein-Style Recommended Guidelines for Uniform Reporting of Data From Drowning-Related Resuscitation: An ILCOR Advisory Statement' [18, 19].

$J B$ is a consulting governor of the Koninklijke Maatschappij tot Redding van Drenkelingen (Royal Society to Rescue People from Drowning, established in 1767), medical advisor for the Royal Dutch Lifeboat Institution (KNRM) and commissioner of the International Life Saving Federation (ILS) on behalf of the Royal Dutch Lifesaving Association (KNBRD).

Al is a volunteer committee member of the American Heart Association, and receives research funding from the US National Institutes of Health, the US Army, the American Heart Association, and HeartSine, Inc. He serves as a volunteer member of the HeartSine Clinical Advisory Board.

No other potential conflicts of interest exist.

\section{Publisher's Note}

Springer Nature remains neutral with regard to jurisdictional claims in published maps and institutional affiliations.

\section{Author details}

'Department of Anaesthesiology, University Medical Center Groningen, University of Groningen, Hanzeplein 1, Huispostcode EB 32, Postbus 30001, 9700 RB Groningen, The Netherlands. ${ }^{2}$ University of Texas Southwestern Medical Center, 5323 Harry Hines Blvd, Dallas, TX 75390-8579, USA. ${ }^{3}$ Research Group Emergency and Disaster Medicine, Vrije Universiteit Brussels, Faculty of Medicine \& Pharmacy, Laarbeeklaan 103, 1090 Brussels, Belgium. ${ }^{4}$ Koninklijke Maatschappij tot Redding van Drenkelingen, Rokin 114, 1012 LB Amsterdam, The Netherlands.

Received: 22 August 2017 Accepted: 14 March 2018

Published online: 22 March 2018

\section{References}

1. Idris AH, Berg RA, Bierens J, Bossaert L, Branche CM, Gabrielli A, Graves SA, Handley AJ, Hoelle R, Morley PT, Papa L, Pepe PE, Quan L, Szpilman D, Wigginton JG, Modell JH, American Heart Association. Recommended guidelines for uniform reporting of data from drowning: the "Utstein style". Circulation. 2003;108:2565-74.

2. Idris AH, Berg RA, Bierens J, Bossaert L, Branche CM, Gabrielli A, Graves SA, Handley AJ, Hoelle R, Morley PT, Papa L, Pepe PE, Quan L, Szpilman D, Wigginton JG, Modell JH, American Heart Association, Maatschappij tot Redding van Drenkelingen, European Resuscitation Council, US Centers for Disease Control and Prevention, University of Florida, University of North Carolina, Australia and New Zealand Resuscitation Council, InterAmerican Heart Foundation, Heart and Stroke Foundation of Canada, Resuscitation Council of Southern Africa. Recommended guidelines for uniform reporting of data from drowning: the "Utstein style". Resuscitation. 2003;59:45-57. 
3. Eich C, Brauer A, Timmermann A, Schwarz SK, Russo SG, Neubert K, Graf BM, Aleksic I. Outcome of 12 drowned children with attempted resuscitation on cardiopulmonary bypass: an analysis of variables based on the "Utstein Style for Drowning". Resuscitation. 2007;75:42-52.

4. Grmec S, Strnad M, Podgorsek D. Comparison of the characteristics and outcome among patients suffering from out-of-hospital primary cardiac arrest and drowning victims in cardiac arrest. Int J Emerg Med. 2009;2:7-12.

5. Youn CS, Choi SP, Yim HW, Park KN. Out-of-hospital cardiac arrest due to drowning: an Utstein Style report of 10 years of experience from St. Mary's Hospital. Resuscitation. 2009;80:778-83.

6. Venema AM, Groothoff JW, Bierens JJ. The role of bystanders during rescue and resuscitation of drowning victims. Resuscitation. 2010;81:434-9.

7. Choi SP, Youn CS, Park KN, Wee JH, Park JH, Oh SH, Kim SH, Kim JY. Therapeutic hypothermia in adult cardiac arrest because of drowning. Acta Anaesthesiol Scand. 2012:56:116-23.

8. Vahatalo R, Lunetta P, Olkkola KT, Suominen PK. Drowning in children: Utstein style reporting and outcome. Acta Anaesthesiol Scand. 2014;58:604-10.

9. Joanknecht $L$, Argent AC, van Dijk M, van As AB. Childhood drowning in South Africa: local data should inform prevention strategies. Pediatr Surg Int. 2015;31:123-30.

10. Kieboom JK, Verkade HJ, Burgerhof JG, Bierens JJ, Rheenen PF, Kneyber MC, Albers MJ. Outcome after resuscitation beyond 30 minutes in drowned children with cardiac arrest and hypothermia: Dutch nationwide retrospective cohort study. BMJ. 2015;350:h418.

11. Hunsucker JL, Davison SJ. Analysis of rescue and drowning history from a lifeguarded waterpark environment. Int J Inj Control Saf Promot. 2011;18:277-84.

12. Allan PF, Fang R, Martin KD, Glenn M, Conger NG. Combat-associated drowning. J Trauma. 2010;69(Suppl 1):S179-87.

13. Ma WJ, Nie SP, Xu HF, Xu YJ, Song XL, Guo QZ, Zhang YR. An analysis of risk factors of non-fatal drowning among children in rural areas of Guangdong Province, China: a case-control study. BMC Public Health. 2010;10:156. https://doi.org/10.1186/1471-2458-10-156.

14. Wanscher M, Agersnap L, Ravn J, Yndgaard S, Nielsen JF, Danielsen ER, Hassager C, Romner B, Thomsen C, Barnung S, Lorentzen AG, Hogenhaven $H$, Davis M, Moller JE. Outcome of accidental hypothermia with or without circulatory arrest experience from the Danish Praesto Fjord boating accident. Resuscitation. 2012;83:1078-84.

15. Orlowski JP, Cramer CL. The drowning risks associated with visiting family or friends. J Pediatr Intensive Care. 2012;1:31-5.

16. Champigneulle B, Bellenfant-Zegdi F, Follin A, Lebard C, Guinvarch A, Thomas F, Pirracchio R, Journois D. Extracorporeal life support (ECLS) for refractory cardiac arrest after drowning: an 11-year experience. Resuscitation. 2015;88:126-31.

17. World Health Organization. Global report on drowning: preventing a leading killer. 2014. http://www.who.int/violence_injury_prevention/global_ report_drowning/en/. Accessed 14 Dec 2017.

18. Idris AH, Bierens JJLM, Perkins GD, Wenzel V, Nadkarni V, Morley P, Warner DS, Topjian A, Venema AM, Branche CM, Szpilman D, Morizot-Leite L, Nitta M, Løfgren B, Webber J, Gräsner J, Beerman SB, Youn CS, Jost U, Quan L, Dezfulian C, Handley AJ, Hazinski MF. 2015 revised Utstein-style recommended guidelines for uniform reporting of data from drowningrelated resuscitation: an ILCOR advisory statement. Circ Cardiovasc Qual Outcomes. 2017;10(7).

19. Idris AH, Bierens JJLM, Perkins GD, Wenzel V, Nadkarni V, Morley P, Warner DS, Topjian A, Venema AM, Branche CM, Szpilman D, Morizot-Leite L, Nitta M, Løfgren B, Webber J, Gräsner J, Beerman SB, Youn CS, Jost U, Quan L, Dezfulian C, Handley AJ, Hazinski MF. 2015 revised Utstein-style recommended guidelines for uniform reporting of data from drowningrelated resuscitation. Resuscitation. 2017;118:147-58.

20. Buick JE, Lin S, Rac VE, Brooks SC, Kierzek G, Morrison ᄂ. Drowning: an overlooked cause of out-of-hospital cardiac arrest in Canada. CJEM. 2013;15:1-8.

21. Nitta M, Kitamura T, Iwami T, Nadkarni VM, Berg RA, Topjian AA, Okamoto Y, Nishiyama C, Nishiuchi T, Hayashi Y, Nishimoto Y, Takasu A. Out-of-hospital cardiac arrest due to drowning among children and adults from the Utstein Osaka Project. Resuscitation. 2013;84:1568-73.

22. Suominen PK, Vallila NH, Hartikainen LM, Sairanen HI, Korpela RE. Outcome of drowned hypothermic children with cardiac arrest treated with cardiopulmonary bypass. Acta Anaesthesiol Scand. 2010;54:1276-81.

23. Hess EP, Campbell RL, White RD. Epidemiology, trends, and outcome of out-of-hospital cardiac arrest of non-cardiac origin. Resuscitation. 2007;72:200-6.
24. Franek O, Pokorna M, Sukupova P. Pre-hospital cardiac arrest in Prague, Czech Republic-the Utstein-style report. Resuscitation. 2010;81:831-5.

25. Foltin GL, Richmond N, Treiber M, Skomorowsky A, Galea S, Vlahov D, Blaney S, Kusick M, Silverman R, Tunik MG. Pediatric prehospital evaluation of NYC cardiac arrest survival (PHENYCS). Pediatr Emerg Care. 2012;28:864-8.

26. Kitamura T, Kiyohara K, Sakai T, Iwami T, Nishiyama C, Kajino K, Nishiuchi T, Hayashi Y, Katayama Y, Yoshiya K, Shimazu T. Epidemiology and outcome of adult out-of-hospital cardiac arrest of non-cardiac origin in Osaka: a population-based study. BMJ Open. 2014;4:e006462. https://doi.org/10.1136/bmjopen-2014-006462.

27. Eschmann NM, Pirrallo RG, Aufderheide TP, Lerner EB. The association between emergency medical services staffing patterns and out-of-hospital cardiac arrest survival. Prehosp Emerg Care. 2010;14:71-7.

28. Papa L, Hoelle R, Idris A. Systematic review of definitions for drowning incidents. Resuscitation. 2005:65:255-64.

29. Donoghue AJ, Nadkarni V, Berg RA, Osmond MH, Wells G, Nesbitt L, Stiell IG, CanAm Pediatric Cardiac Arrest Investigators. Out-of-hospital pediatric cardiac arrest: an epidemiologic review and assessment of current knowledge. Ann Emerg Med. 2005:46:512-22.

30. Schilling UM, Drowning BM. Minerva Anestesiol. 2012;78:69-77.

31. Szpilman D, Bierens JJLM, Handley AJ, Orlowski JP. Current concepts drowning. N Engl J Med. 2012;366:2102-10.

32. Tourigny PD, Hall C. Diagnosis and Management of Environmental Thoracic Emergencies. Emerg Med Clin North Am. 2012;30:501.

33. Bjornsson HM, Marelsson S, Magnusson V, Sigurdsson G, Thornorgeirsson G. Prehospital cardiac life support in the Reykjavik area 1999-2002. Laeknabladid. 2006;92:591-7.

34. Hausser J, Drowning NM. Rev Med Suisse. 2007:3:1834-8.

35. Schmidt A, Sempsrott J. Near drowning and adult respiratory distress syndrome. J Emerg Med. 2015;48:e47.

36. Bierens JJ, Warner DS. Drowning resuscitation requires another state of mind. Resuscitation. 2013;84:1467-9.

37. Sempsrott J, Slattery D, Schmidt A, Penalosa B, Crittle T. Systematic review of non-Utstein style drowning terms. Ann Emerg Med. 2011;58:S321.

38. Warner DS, Bierens JJLM, Beerman SB, Katz LM. Drowning a cry for help. Anesthesiology. 2009;110:1211-3.

39. van Beeck E, Branche C, Szpilman D, Modell J, Bierens J. A new definition of drowning: towards documentation and prevention of a global public health problem. Bull World Health Organ. 2005;83:853-6.

40. Lunetta P, Modell J, Sajantila A. What is the incidence and significance of "dry-lungs" in bodies found in water? Am J Forensic Med Pathol. 2004;25: 291-301.

41. Lence EM, Ramos NG, Carriedo CS, Garcia-Ochoa JMB, Corral ET. Out-ofhospital cardiorespiratory arrest in children with trauma. Resuscitation. 2014;85:S92

42. Newton T, Patterson LZ, Cindrich LA, Sills R, Babcock Cl. Outcome of out-ofhospital infant cardiac arrest presenting with asystole as initial rhythm. Ann Emerg Med. 2013;62:S143-4

43. Shin SD, Ro YS, Song KJ, Lee EJ, Ahn KO. Epidemiology and outcomes of emergency medical services-assessed out-of-hospital cardiac arrest in Korea: a nationwide observational study from 2006 to 2010. Circulation. 2012;126: A230.

44. Lin C, Chiang W, Chi C. Use of automated external defibrillators in patients with traumatic out-of-hospital cardiac arrest. Resuscitation. 2012;83:e61.

45. Tijssen J, Zhan C, Parshuram C, Morrison L, Hutchison J. Critical times in pediatric out-of-hospital cardiac arrest. Crit Care. 2012;16:597-8.

46. Webber JB. Drowning, the New Zealand way: prevention, rescue, resuscitation. Resuscitation. 2010;81:S27

47. Williams B, Panchal AR, Stolz U, Clark L, Bobrow B, Sanders AB. Cardiocerebral resuscitation improves survival and neurological outcome from out-of-hospital cardiac arrest. Acad Emerg Med. 2010;17:S143.

48. Auerbach PS, Zafren K. Environmental emergencies: drowning. In: An introduction to clinical emergency medicine; 2012. p. 641-72.

49. Quan L, Bierens JJLM, Lis R, Rowhani-Rahbar A, Morley P, Perkins GD. Predicting outcome of drowning at the scene: a systematic review and meta-analyses. Resuscitation. 2016:104:63-75. 